\title{
Art and Architecture in the Jesuit China Mission: Recent Trends in Cultural Transnational Studies
}

\author{
Wang, Lianming \\ Jesuitenerbe in Peking: Sakralbauten und transkulturelle Räume, 1600-180o. \\ Heidelberg: Universitätsverlag Winter, 2020. Heidelberg Transcultural Studies, \\ 5. Pp. 479. Hb, € 68,oo.
}

\section{Steffen Zierholz}

Räume der Reform: Kunst und Lebenskunst der Jesuiten in Rom 1580-1700. Berlin: Gebr. Mann Verlag, 2019. Pp. 288. Hb, € 69,oo.

In 1635, two men of letters published a cultural guidebook to Beijing. In Dijing jingwu lüe (Sights and monuments of the imperial capital), Liu Tong and Yu Yizheng described the history and appearance of dozens of worthy sights, among them, the Church of Immaculate Conception, called by locals Nantang, the southern church, after its location south of the Xuanwumen, one of the nine gates that separated the Forbidden City from the rest of the imperial capital. Today, a church still stands on that site, constructed in 1904 in neo-baroque style; earlier versions of that Jesuit residence and church were long since lost to earthquakes, fire, and turmoil. This site was originally purchased in 1605 by Matteo Ricci (1552-1610), after he had received permission to reside in the Ming capital. The neighborhood influenced Ricci's choice: a hub of inns and banks, the Xuanwumen District was frequented by candidates from all over the realm who traveled to Beijing for the triennial civil service examination, the ultimate pinnacle in a long and elaborate ascent of the heights of examination hell, the success of which promised a paradise of reputation, power, and fortune. Scholars, literati, magistrates: these were Ricci's men, his discursive partners, transmitters of a moral-philosophical tradition that reminded him of Christianity, the Chinese equivalents of Greek Stoics, whose conversion would bring the entire country to the true faith, so hoped the Italian missionary. There, in his new residence, with a room set up for church services, and another for the exhibition of Western books, clocks, and scientific instruments, Ricci would charm, captivate, and convert them, the future Christian elites of China. Into this open compound Liu and Yu would wander, marveling at the curious decorations and cultural 
artefacts of these foreigners. In the chapel they were enchanted by a central painting representing a woman carrying a male infant, "vivid and life-like," unlike anything they had seen before in Chinese portraits. This picture of Madonna and Child was a copy of the original at the Santa Maria Maggiore in Rome. Entering the real space of the Jesuit church, Chinese visitors were enthralled by the chiaroscuro and perspectival vision of European painting to enter yet another space, a deceptive one, in which the glory of the Christian deity was vividly depicted.

The application of geometry in perspectival painting, the use of colors to create the effects of light, and the interplay between architecture, the plastic, and fine arts that so impressed the Chinese represented the great achievements in European art between the Renaissance and the baroque. Jesuit missionaries were the transmitters of this culture to late Imperial China, where they hoped their expertise would further evangelization. As artists and architects (or for that matter mathematicians or musicians), the Jesuits were above all pragmatic, responding to Chinese demands and tastes. After all, Beijing was not Rome; and the fathers were not masters of their own house. Recent scholarship on the Christian cultural heritage in China has emphasized the hybrid nature of that artistic exchange and the very different contexts for the creation and reception of Western art and architecture. This essay will first describe architecture and art in the Jesuit China Mission by reviewing the latest trends in scholarship, and then reflect on the significance of that scholarship on the debate on Jesuit art in Europe.

Returning to the Nantang, the Church of Immaculate Conception, we can follow the history of its expansion. To the original private house purchased by Ricci, the Jesuits added space after acquiring a neighboring academy. The real expansion, however, occurred in 1650 when the German Jesuit astronomer, Adam Schall von Bell (1591-1666), a favorite and paternal figure to the first Qing emperor, the young Shunzhi (r.1644-61), received state funds for new constructions. An imperial favor for the embellishment of the emperor's favorite Western courtier came to be represented by the Jesuits themselves as an imperial ecclesiastical foundation, a myth thoroughly debunked by Wang Lianming, an architectural historian at the University of Heidelberg, whose excellent book on the Jesuit artistic heritage in Beijing represents the best study of the topic that has appeared as yet. Using blueprints, visual images, and archival documents, Wang has carefully reconstructed the appearance of the Jesuit churches in Beijing and even constructed models of these compounds. He has offered a nuanced analysis of the artistic heritage of the Jesuits in a broad historical context. 
In 1703, the Nantang underwent yet another renovation under the superior of the Portuguese Jesuit vice-provincial, Tomás Pereira (1645-1708), a court musician to Emperor Kangxi (r.1661-1772), and an implacable foe of the more recently arrived French Jesuits, who had refused to acknowledge Portuguese patronage over all Asian missions as defined by the 1496 Treaty of Tordesillas granted by the papacy, and insisted on Gallican liberties and the rival royal patronage of Louis XIV (r.1643-1715). This version of the Nantang became the grandest sacral monument yet, with a façade that resembled the Portuguese tropical style combining Manueline stylistic elements and decorative features common to Portuguese Goan churches. It stood as a monument to Portugal's patronage of Christianity in Asia and a response to the French Jesuit church that had just gone up in the same year, 1703. This new church of Our Savior was built on land granted in 1694 by Emperor Kangxi to the French Jesuits as a reward for their role in curing him from a recurrent attack of smallpox, a disease he had contracted as a child.

A comparison of the Northern and Southern churches reviews not only the different national architectural styles of France and Portugal, but also the profoundly divergent social and political functions of these two Jesuit churches in the same city. First, their foundations. As we have seen, the Nantang began as a private purchase by Ricci and, while it received imperial subsidies, never acquired an official status. In contrast, the Beitang of the French Jesuits was built on land granted by the emperor and its layout revealed Kangxi's idea of constructing an imperial academy/ workshop centered around the French Jesuits. Far from being just a sacral building, the Beitang included ample living quarters with houses built in Chinese style, extensive gardens, a glass-making workshop, and an observatory. Unlike the Nantang, the compound of Our Savior lay in the Forbidden City in proximity to the imperial palace and hence inaccessible to all but official visitors.

Second, the gardens. Both the Nantang and the Beitang had gardens. Whereas the much smaller Nantang garden was used to grow grapes and other plants, for consumption of the Portuguese fathers, their French confrères imported the idea of their garden at La Flèche, where a geometrically formed courtyard garden at the French Jesuit college, with trees planted at regular intervals in a parterre geometrical decoration symbolized the perfect order of paradise. Instead of being relegated to the backside of the compound, the garden formed the courtyard of the Northern Church. Divided into quarters with Chinese and European plants placed at regular intervals, this orderly space, the symbol of paradise, is the forecourt of the sacral church realm where divinity dwells. All this and more are painstakingly reconstructed by Wang from drawings, plans, 
and paintings, since the original church is long gone, and the present building in Beijing does not even occupy the same site. Impressive indeed is Wang's attention to details, to the extent that he has identified every plant depicted in a painting of the Beitang garden. European flora was transplanted to China and vice versa; garden art was more than a transcultural moment: it represented a scientific exchange of medical and botanical knowledge across continents.

There was a third Jesuit church in old Beijing, St. Joseph's, where the Jesuits had their college. Like the Nantang, it belonged to the Portuguese vice-province and came to be called by the locals Dongtang, the Eastern Church, in relationship to the two more famous sister churches. Fewer drawings and paintings are extant of St. Joseph's; and although there are no blueprints showing the layout of the sacral interior, Beijing maps clearly indicated its location. Situated outside of Donghuamen, one of the nine gates of the Forbidden City, St. Joseph's, located to the east of the Imperial Palace, today occupies its original 1653 site, on Wangfujing, Beijing's most famous shopping street. The present church was rebuilt in 1904 in romanesque revival style, the original having suffered the fates of its sister Jesuit churches in the capital. To study this less famous church, Wang consults the descriptions of Korean envoys in the Yeonhaeng nok, since the Korean residence was serendipitously situated in the neighborhood of the Dongtang. If there is one conclusion to the many descriptions by Korean envoys over the generations, it is that they were awed by the combination of decorative, aesthetic, architectural, mechanical, and scientific elements of St. Joseph's. Readers may hesitate to agree with Wang's characterization of Jesuit churches as "proto-museums" - they were not after all Athanasius Kircher's (1602-80) exhibition space in Rome-but clearly Jesuit sacral buildings (and art) must be understood in a larger social, spatial, cultural, and political context.

There are two questions that can help us see the larger picture. First, what is the relationship between techne ( $\tau \varepsilon \chi \nu \eta)$ and energeia ( $\varepsilon \varepsilon \varepsilon p \gamma \varepsilon i \alpha)$ in Jesuit artistic production? Aristotle defines energeia as a state of actuality, the ful-

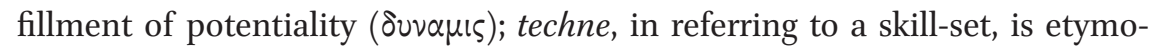
logically related to the modern word, technology. In a recent study of the two Jesuit churches in Rome-Il Gesù and San Ignacio-Steffen Zierholz uses the concept of energeia to analyze Jesuit art. How did Jesuit sacred space- - by this he refers primarily to the interior space of San Ignacio as designed by Andrea Pozzo (1542-16o9) - express their corporate ethos, which was modeled after the exemplar of their founder and enshrined in a central text, the Spiritual Exercises? Beyond the Roman Jesuit churches, this approach can be applied to analyze all Jesuit overseas missions and the role of culture in Christian evangelization. If human beings are created in the image of God and have the 
potential to actualize their divine nature, what are the methods that might bring this about? Seen in this context, all Jesuit artistic production (indeed all Jesuit activity) can be interpreted as a technique of the self, as Michel Foucault (1926-84) would define. Therefore, one can understand Jesuit art and architecture as examples of "our way of proceeding." The second question is closely related to this first: in expressing the Jesuit "way of proceeding" in a missionary terrain far from the home ground of Catholic Europe, what would this transcultural moment look like? How were Jesuit churches and art in China different, if at all, from similar cultural objects in the West? Before we can answer these questions, we must once again beat a dead horse, Jesuit style, for the simple reason that this confused and unhelpful thing has obscured a better view of the picture.

Even in his path breaking book, Wang feels obliged to discuss the 1972 work by Rudolf Wittkower and Irma Jaffe. ${ }^{1}$ Was the baroque a Jesuit invention? Was their mother church, Il Gesù, the first example of a baroque church? A sensible book, Baroque Art demonstrates the multiplicity of styles in Jesuit churches, especially in northern Europe, and doubts the existence of any unified Jesuit style. They were not the first art historians to demonstrate this. In his recent essay, Jeffrey Muller reminds us that as early as 1907 Joseph Braun wrote: "Das Wort Jesuitenstil is eine Name ohne Inhalt, ein Wort ohne Sinn" (The word Jesuit style is a name without meaning, a word without meaning). ${ }^{2}$ His conclusion is based on an extensive study of German Jesuit churches, where the late gothic, rather than the baroque, played a much more prominent stylistic role. If such a strong stylistic difference existed between German and Italian Jesuit, might not the correct solution be the one preferred by Wang Liangming: to decenter the European focus of Jesuit sacral architecture and to analyze the moments of transcultural encounters?

Wang's monograph is of course a splendid example of decentering Europe by offering the reader his impressive knowledge of both European and Chinese sacral architecture. While European (and specific Jesuit) decorative and architectural elements were exported to China, Jesuit artistic production itself was deeply influenced by Chinese demand and taste. The eighteenth-century French Jesuit artist, Dennis Attiret (1702-68), who worked in the court of Emperor Qianlong, wrote: "The manner of building in this country pleases me

1 Baroque Art: The Jesuit Contribution (New York: Fordham University Press, 1972).

2 Cited in Jeffrey M. Muller, "Historiography of the Art and Architecture of the Jesuits," in Jesuit Historiography Online, ed. Robert A. Maryks, http://dx.doi. org/10.1163/2468-7723_jho_SIM_192594. 
very much. Since my residence in China, my eyes and taste are grown a little Chinese [...]. Every country has its taste and customs."3

His modified architectural taste notwithstanding, Attiret joined a team of Jesuit experts in designing a Western-style palace at the Yuanmingyuan, the suburban Summer Palace favored by the Qianlong emperor. A European villa was constructed with parallel staircases, fronted by a fountain with water-spouting sculptures, propelled by the hydraulic know-how of Jesuit missionaries. This was the site where Qianlong entertained European envoys, in a demonstration of his claims to imperial universality, before a joint Franco-British army looted and burned the Summer Palace in 186o.

As an example of transnational cultural transmission, the Yuanmingyuan European Palace was unique. ${ }^{4}$ Wang analyzes in detail Chinese hydraulics, Jesuit engineering, and the symbolic value of the European villa/ garden in Qing imperial ideology. But is this a case of techne actualizing energeia? And how was Jesuit expertise being used for Christian evangelization? Wang admitted as much. Jesuit aesthetics and expertise were widely used for secular purposes. He gives us other examples: the use of trompe l'oeil, famously designed by Andrea Pozzo in Rome for Il Gesù to promote the forty-hour devotion and for the dome of San Ignacio, being used in Beijing for stage settings for imperial birthdays and the like. This deviated far from the Jesuit way of proceeding, in which techne created a moment of divine inspiration, as when a painting drops down by ropes and pulleys in front of the altar dedicated to St. Ignatius in the Roman church of the same name, to reveal a statue of the founder looking up to heaven. Here, mechanics enables an imago agens, an actualization of energeia. ${ }^{5}$ The artistic apex of the Jesuit way of proceeding may be represented by Pozzo's renovations in San Ignacio, as Zierholz recently argues, in which all artistic forms and techniques-trompe l'oeil, representation of three-dimensional space on flat surfaces through perspectival painting, the entwining of sculpture and paints, the use of mechanics and light-were employed to actualize the original Ignatian moment. The call by Christ to his banner, Ignatius's acceptance of the cross, and his paternal example to all sons of the Society: these constituted the textual commonplaces for the design of Jesuit space and aesthetic, for the turning of the soul to God.

3 From Lettres édifiantes cited in Muller, "Historiography of the Art."

4 Although it is used recently for stylistic comparison with Brazilian Jesuit churches by Gauvin Alexander Bailey, "Missionary Art and Architecture of the Society of Jesus between China and Brazil," in Oxford Handbook of the Jesuits, Ines G. Županov, ed. (Oxford: Oxford University Press, 2019), 487-520.

5 See Mia M. Mochizuki, "Jesuit Visual Culture in a Machine Age," in Oxford Handbook of the Jesuits, 449-86. 
But Beijing was not Rome; there, the Jesuits were not masters of their space. In the Qing imperial capital, all Jesuit expertise served the emperor. Take a further example, the fine arts: the series of canine and equine portraits painted by the Italian Jesuit brother, Giuseppe Castiglione (1688-1766), pioneer of a synthetic Sino-European style, whose works still grace the National Palace Museums in Beijing and Taipei. Did Castiglione and Attiret, or any of the Jesuit mathematicians, astronomers, physicians, and musicians thought of their service in the imperial court as evangelization? Attiret might complain of the tedium of painting imperial portraits (of which he produced many exquisite ones), "if it were not for the work of salvation," ${ }^{6}$ but the Bohemian Jesuit and musician Florian Bahr (1706-71) was happy enough that Qianlong was uninterested in Western music and never called upon his musical expertise, leaving him more time to minister to his common parishioners. Surely, at some time, even the most hopeful missionary in Beijing had given up on the dream of Qianlong's conversion, if not in 1746-48, when the first European missionaries (Spanish Dominicans) were arrested by a hostile governor and executed in prison, then certainly by 1785 , when the emperor ordered a crackdown on clandestine missionaries and Christians in all corners of his realm. If the expertise, the techne of the Jesuits, had failed to convert China (that might have been a tall order to begin with), what was the point of "our way of proceeding"? In their defense, we could say, thanks to these Jesuit missionaries, there were important moments of cultural transmission otherwise missing in the transnational history of the early modern world.

These moments of cultural transmission might best be approached by looking at some recent scholarship on Jesuit missionary art that focuses on the Virgin Mary. Let us recall the 1635 cultural guide to Beijing in which a painting of Madonna and Child graced the altar and so impressed the two Chinese visitors. Female deities were familiar to Chinese of the Great Ming, not only the ubiquitous bodhisattva Guanyin (Avalokitesvara in Sanskrit), but also the goddess Mazu, the Consort of Heaven, protectress of all seamen, whose cult was especially widespread in the maritime provinces. A favorite representation of Guanyin, in paintings and statues, shows her as a presenter of male infants to her devotees. Is it any wonder that many Chinese in the late Ming confused the Virgin Mary with Guanyin?? ${ }^{7}$ Even Portuguese priests mistook one for the other: Gaspar da Cruz, a Portuguese

6 Muller, "Historiography of the Art."

7 Gang Song, "Between Bodhisattva and Christian Deity: Guanyin and the Virgin Mary in Late Ming China," in Deepak Shimkhada and Phyllis K. Herman, eds., The Constant and Changing Faces of Goddess: Goddess Traditions of Asia (New Castle, UK: Cambridge Scholars Publishing, 2008), 101-20. 
Dominican, who visited Guangzhou and published in 1569 one of first personal accounts of China, saw a statue of Guanyin in a Buddhist temple and speculated that it must have represented a remnant of the Marian cult that had once existed in China. ${ }^{8}$ The same mistake was made by the young Portuguese Jesuit António Almeida. In 1584, he accompanied Michele Ruggieri (1543-1607), the senior Jesuit China missionary, on a trip from Guangdong in the south to Zhejiang province in central China. During their voyage, they encountered Buddhist monks and visited Buddhist temples, where Almeida saw a painting of Guanyin represented in one of her many manifestations as a princess, a daughter of the Dragon Sea King, and thought of the figure as perhaps representing the Virgin Mary. ${ }^{9}$ To avoid confusion, and to dispel the talk that their god was a woman, the Jesuits in Beijing eventually replaced the portrait of Madonna and Child with a painting of Christ (although not the crucified Jesus) as the main altar picture in their Southern Church.

The figure of Mary struck a deep chord in Chinese hearts. Goddesses were present when their world was created; female deities would intervene, to deliver safe childbirths, to save travelers, reward the pious, the just, and the filial; to redeem the myriad sufferers in crises, when their world-order was cracking and crumbling amidst floods, famines, and rebellions at the end of dynasties. When Christians dreamed in late imperial China, they saw the Mother of God more than any other figures; when Buddhists dreamed, they often saw the bodhisattva. ${ }^{10}$ The Virgin Mary was the central figure with many faces in the early modern Christian mission, a focus of confraternal devotion, prayers, and visual representations, as reflected in the many sources consulted by Song Gang in a recent study of Marian devotion. ${ }^{11}$

The visual evidence of Marian devotion is analyzed in four recent articles by Chen Hui-hung, an art historian by training and a historian of the Christian

8 Gaspar da Cruz, Tractado em que se contam muito por extenso as cousas da China (1569). English translation in Charles R. Boxer, South China in the Sixteenth Century: Being the Narratives of Galeote Pereira, Fr. Gaspar da Cruz, and Fr. Martin de Rada (London: Hakluyt Society, 1953).

9 R. Po-chia Hsia, A Jesuit in the Forbidden City: Matteo Ricci 1552-1610 (Oxford: Oxford University Press, 2010).

10 See my "Zong jiao xinyang yu meng wenhua: Ming Qing zhiji tianzhujiao yu fojiao de bijiao tansuo" 宗教信仰與夢文化 : 明清之際天主教與佛教的比較探索 (Religious Beliefs and Dream Cultures: A Comparative Analysis of Catholicism and Buddhism in the Late Ming and Early Qing)," Bulletin of the Institute of History and Philology: Academia Sinica 76, part 2 (2005): 209-48.

11 Song Gang, "The Many Faces of Our Lady: Chinese Encounters with the Virgin Mary between 7th and 17th Centuries," Monumenta Serica 66, no. 2 (2018): 303-56. 
mission in late imperial China. ${ }^{12}$ The first Marian picture transmitted to China was the Madonna and Child mentioned above, a copy of the original in Santa Maria Maggiore in Rome, reputed to be painted by St. Luke. The image was also called the Salus Populi Romani, and in its Chinese translocation, it is known also as the Salus Populi Sinensis. Around the same time, the image of Santa María de la Antigua from the Seville cathedral was also transmitted to China via Mexico and Japan. Produced in different artistic media, the Spanish Virgin made her way from painting in Spain to copper engraving in Japan, and finally to woodblock print in China. An acquaintance of Matteo Ricci included this Marian image when he published selected works from his private collection of calligraphy and paintings, in Cheng Shi Moyuan 《程氏墨苑》(Cheng's ink garden, 1610).

The Sinicization of Christian art, Chen argues, is reflected not only in the reproduction of a Marian image for a secular art collection, reducing the sacred to the curious, not dissimilar to the channeling of Jesuit techne for secular Qing imperial aims. Even when imported Christian images were explicitly reproduced for religious purposes, the new artistic forms expressed unmistakable signs of Sinicization. A beautiful color scroll of Madonna and Child, named the Xian Madonna after the site of its acquisition, and since 1904 part of the exquisite Chinese collection in Chicago's Field Museum, depicts a Chinese woman holding a Chinese boy, dressed in Ming dynasty costumes. There is no scholarly consensus to the provenance of this scroll: some argued for the late Ming, others for the eighteenth century; and while the majority of art historians agree

12 Hui-Hung Chen (陳慧宏), “Cong shiqi shiji liang jian shiliao kan shengmu de shijieshi mailuo: Xibanya, Riben, he Zhongguo de yige kuayu jiaoliu” 從十七世紀 兩件史料看聖母的世界史脈絡：西班牙、日本和中國的一個跨域交流 (The world-historical contexts of the Virgin Mary seen from two seventeenth-century sources: cross-boundary encounters of Spain, Japan, and China), Hanxue yanjiu 漢學研究 (Chinese Studies) 37, no. 4 (2019): 321-93; Hui-Hung Chen, "Liang fu yesuhuishi de shengmu shengxiang: jianlun Mingmo tianzhujiao de 'zongjiao'" 兩幅耶穌會士的聖母聖像：兼論明末天主教的「宗教」(Two Jesuit Madonna icons: Religious dimensions of Catholicism in late-Ming China), Taida lishi xuebao 臺 大歷史學報 (Historical Inquiry) 59 (June 2017): 49-118; Hui-Hung Chen, "Cong yesuhui de luoma shengmu shengxiang kan zhongguo shengmu de tezhi han qi shijieshi mailuo” 從耶穌會的羅馬聖母聖像看中國聖母的特質和其世界史脈絡 (The characteristics of the Virgin Mary in China and its world-historical contexts based on the Madonna icon in the Santa Maria Maggiore), Zhongyang yanjiuyuan jindaishi yanjiusuo jikan 中央研究院近代史研究所集刊 (Bulletin of the Institute of Modern History) 111 (March 2021) (forthcoming); Hui-Hung Chen, "Shaping the Anthropological Context of the "Salus populi Sinensis": Madonna Icon in Xian, China," in Encounters between Jesuits and Protestants in Asia and the Americas, ed. Jorge Cañizares-Esguerra, R. P. Hsia, and Robert Aleksander Maryks (Leiden: Brill, 2018), 90-116. 
on the Christian identity of mother and child, Chen reminds us that there are enough iconographic ambiguities to suggest the scroll might have represented the Son-Giving-Guanyin, or an ambivalent fusion between the Christian and Buddhist mothers. In the context of the last interpretation, Sinicization means more than the accommodation of Jesuit techne and Christian art to Chinese aesthetics, it implies a thorough hybridization of religious and artistic modes, in which a transcendent maternal figure, with her multivalent charisma in different cultures, played a far more significant role than male-centered Confucianism in the appropriation of Christianity.

As creators of Marian sodalities, the Jesuits were great promoters of the Mother of God in late imperial China. For their Marian sodalities, the Portuguese Jesuit João da Rocha $\left(15^{6} 5^{-1623)}\right.$ translated Gaspar Loarte's (1498-1578) Method for Reciting the Rosary into Chinese as Song nianzhu guichen 誦念珠規程 and included it in a catechism, Tianzhu shengjiao qimeng, 天主聖教啟蒙 with fifteen woodcuts that illustrate the lives of Mary and Jesus. A double translation was involved, between languages (Italian and Chinese) and images (Flemish engravings and Chinese woodcuts). In fact, the woodcuts were modeled after the original engravings produced by the famous Wiericx brothers in Antwerp, who etched 153 engravings for Jerónimo Nadal's (1507-80) illustrated Evangelicae historiae imagines (1593). A close companion of Ignatius, although not among his first companions, Nadal became one of the most prominent first-generation Spanish Jesuits. Arranged according to feast days, thick with biblical citations and meditations, the Imagines was commissioned by Ignatius as a guide for practicing the Spiritual Exercises. Given the Ignatian exhortation to visualize the life of Christ in mental prayers, Wiericx's engravings were created with great artistic and technical skills. Published after the death of Nadal, the Imagines was the most elaborately illustrated book in the publishing history of the Society of Jesus. The fathers in China had a copy. They used it for good purposes. In addition to da Rocha's Method for the Rosary, the Italian Jesuit Giuglio Aleni selected fifty-three illustrations for his story of Christ, the Tianzhu jiansheng chuxiang jingjie (1637). ${ }^{13}$ To save cost, the original number of images in Nadal were reduced to one-third; wood blocks replaced copper plates; and the "translated" images were simpler, cruder, but acquired a distinctive Chinese style. From floor design, wall patterns, background gardens, subtle facial features, to the inclusion of Chinese men and women adoring the Virgin Mary ascendant in Heaven-figures that were naturally not in Nadal's original engraving - these woodcuts represented a primary example

13 The Tianzhu jiangsheng chuxiang jing jie天主降生出像經解 (Biblical explanations and illustrations of the heavenly lord's incarnation, abbreviated Chuxiang (first edition 1637). 
where techne and energeia were actualized in a transcultural moment, where Sinicization was a byproduct of the Jesuit way of proceeding, where every technique and aesthetic was used to inspire a spiritual turn. This may constitute the heart of the paradox: the absence of a "Jesuit style" belies a profound unity in the Jesuit way of proceeding, in which all art and artifice led to action for the sake of salvation.

\section{R. Po-chia Hsia}

Department of History, Penn State University, State College, PA, USA rxh46@psu.edu 